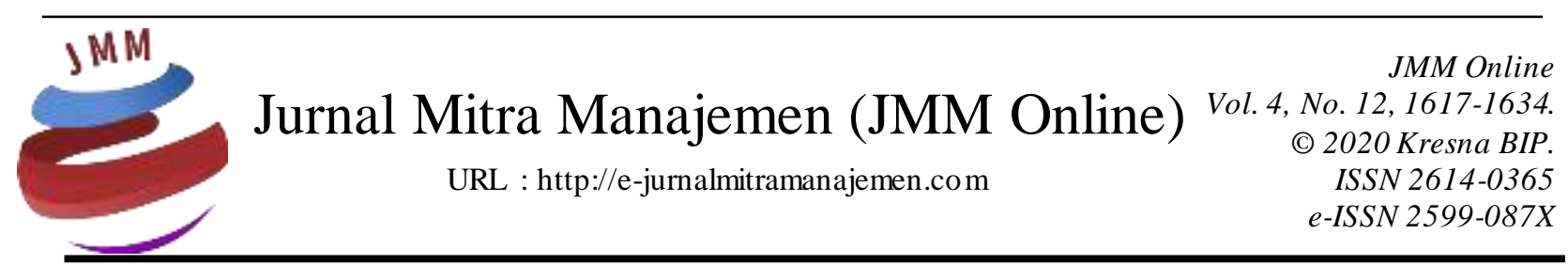

\title{
PENGARUH HARGA, KUALITAS PRODUK DAN CITRA MEREK TERHADAP MINAT BELI PADA TWO GOOD BAKERY
}

\author{
Nicholas Francois Gunawan \\ Universitas Ciputra Surabaya
}

\section{INFORMASI ARTIKEL}

Dikirim : 16 Desember 2020

Revisi pertama : 17 Desember 2020

Diterima : 18 Desember 2020

Tersedia online : 08 Januari 2021

Kata Kunci: Harga, Kualitas Produk, Citra Merek, Minat Beli

Email :nickefge@gmail.com

\section{ABSTRAK}

Penelitian ini bertujuan untuk mengetahui pengaruh Harga, Kualitas Produk, dan Citra Merek terhadap Minat Beli pada produk Two Good. Pendekatan penelitian yang dilakukan adalah kuantitatif. Teknik pengambilan sampel yang digunakan adalah nonprobability sampling dengan metode purposive sampling. Jumlah sampel dalam penelitian ini sebanyak 98 responden. Metode pengumpulan data dalampenelitian ini menggunakan kuesioner diukur dengan menggunakan skala Likert dan data yang terkumpul dianalisis menggunakan regresi linier berganda. Hasil penelitian menunjukkan Harga berpengaruh positif signifikan terhadap Minat Beli produk Two Good, Kualitas Produk berpengaruh positif signifikan terhadap Minat Beli produk Two Good. Sementara Citra Merek tidak berpengaruh negatif signifikan terhadap Minat Beli produk Two Good. 


\section{PENDAHULUAN \\ Latar Belakang}

Perekonomian di Jawa Timur terus berkembang pesat. Perkembangan ekonomi ini selain karena pertambahan jumlah penduduk juga sebagai dampak berbagai peluang bisnis yang diciptakan oleh para pengusaha. Diantara banyak peluang bisnis yang ada, industri bisnis makanan di Jawa Timur juga meningkat signifikan.

Salah satu industri makanan yang perkembangannya cukup menjanjikan adalah di bidang bakery, seperti spiku. Secara khusus di wilayah Surabaya, persaingan bisnis spiku menunjukkan tren yang semakin ketat. Beberapa jenis produk spiku terus merambah ke pasar di Surabaya antara lain Spikoe Resep Kuno, Livana Spikoe, Cristine Spiku, Spika Butter Spiku.

Produk-produk spiku di atas merupakan merek yang hak kepemilikannya adalah produsen di kota Surabaya. Two Good merupakan perusahaan yang berbasis online dan bergerak di bidang makanan dengan produk berupa spiku. Perusahaan ini mulai berdiri pada bulan Januari 2018. Dari berbagai merek yang yang dikenal di pasar bakery, Two Good Bakery menetapkan untuk bertarung secara head-to-head dari segi harga dan kualitas produk dengan merek Spikoe Resep Kuno dan Livana Spikoe.

Perusahaan Two Good didirikan karena adanya peluan besar dalam industri makanan di Jawa Timur. Selain itu, Two Good ingin memberikan diferensiasi dalam industri makanan spiku dengan berbagai inovasi dari segi isi, rasa dan penyajiannya. Perusahaan Two Good menghadirkan 4 (empat) rasa, yaitu original, coklat, keju dan teh hijau. 4 (empat) menu ini disajikan melalui ukuran $20 \times 20 \mathrm{~cm}$ dengan harga jual Rp 100,000 per kotak. Target pasar Two Good adalah penduduk Surabaya yang berusia 16-55 tahun dari kelas menengah ke atas. Two Good berencana membuka ruko di daerah Pakuwon City, lebih tepatnya di daerah ruko San Diego.

Menurut penelitian Prasetyo dan Purwantini (2017), faktor-faktor kualitas produk, citra merek dan harga secara serempak berpengaruh signifikan terhadap keputusan pembelian produk laptop Toshiba. Hasil penelitian ini menjadi ide dasar untuk melakukan survei awal bagi calon konsumen Two Good yang pernah membeli merek spiku kompetitor. Pertanyaan untuk survei awal di dalam penelitian ini adalah "Apa yang menjadi pertimbangan utama Anda dalam pembelian spiku?". Pilihan jawaban yang diberikan untuk calon konsumen Two Good ada tiga jawaban, yaitu harga, kualitas produk, dan citra merek. Masing-masing calon konsumen yang belum pernah membeli produk Two Good tetapi pernah membeli spiku merek lain hanya boleh memilih 1 dari 3 jawaban yang tersedia. Besar responden yang telah ditetapkan sebagai responden di dalam survei awal ini adalah 50 responden.

Menurut survei terhadap 50 responden, ditemukan dua dari tiga variabel dalam pembelian spiku yang paling banyak dipilih di atas 30\%. Sebanyak 17 responden memilih variabel harga dengan presentase sebesar 34\%. Sebanyak 18 responden memilih variabel kualitas produk dengan presentase sebesar 36\%. Sebanyak 15 responden memilih variabel cita merek sebesar 30\%. Melihat adanya 3 (tiga) variabel dalam pembelian spiku yang dipilih di atas atau sama dengan 30\%, maka diputuskan untuk menelusuri nama atau brand dari produk kompetitor yang pernah dibeli para responden tersebut berdasarkan pilihan variabel. 
Sebanyak 17 responden memilih variabel harga dalam membeli produk kompetitor. Sebanyak 13 dari 17 responden memilih produk Spikoe Resep Kuno. Sebanyak 2 dari 17 responden memilih produk Livana Spiku. Sebanyak 1 dari 17 responden memilih produk Spiku Ny. Hartono. Sebanyak 1 dari 17 responden memilih produk Christine Spiku. Hal ini menunjukkan bahwa produk Spikoe Resep Kuno dan Livana Spiku memiliki harga yang sesuai yang diminati oleh masyarakat kota Surabaya. Produk Spikoe Resep Kuno dan Livana Spiku dapat menjadi acuan bagi penelitian dalam mempelajari faktor-faktor yang dapat membuat harga yang menarik minat beli konsumen.

Menurut Tjiptono \& \& Chandra (2012), secara sederhana harga bisa Perusahaan Two Good memiliki harga jual kisaran $\mathrm{Rp}$ 100.000. Harga jual ini tergolong mahal karena harga Spikoe Resep Kuno lebih murah dengan kisaran $\mathrm{Rp}$ 90.000 dan Livana Spiku dengan kisaran Rp 80.000. Harga produk ditentukan berdasarkan atas kualitas bahan baku yang digunakan oleh masing-masing perusahaan dalam menghasilkan makanan tersebut. Semakin tingkat harga bahan baku yang digunakan, maka semakin mahal harga jual yang ditetapkan perusahaan; demikian sebaliknya.

Selain faktor harga, kualitas produk juga menjadi acuan keputusan pembelian konsumen. Hasil penelitian awal yang dilakukan menunjukkan sebanyak 18 responden memilih variabel kualitas produk dalam membeli produk kompetitor. Sebanyak 12 dari 18 responden memilih produk Spikoe Resep Kuno. Sebanyak 6 dari 18 responden memilih produk Livana Spiku. Hal ini menunjukkan produk Spikoe Resep Kuno dan Livana Spiku merupakan produk yang berkualitas yang diminati oleh masyarakat kota Surabaya. Produk Spikoe Resep Kuno dan Livana Spiku dapat menjadi acuan bagi penelitian dalam mempelajari faktor-faktor yang dapat membuat kualitas produk yang dapat menarik minat beli konsumen.

Perusahaan Two Good belum memiliki daya guna terkait dengan kualitas produk. Sementara Spikoe Resep Kuno dan Livana Spiku memiliki daya guna, yaitu menjadi sajian ramah tamah acara kantoran, ibadah, dll sebagai bentuk pengakuan daya guna produk perusahaan. Perusahaan Two Good juga memiliki daya tahan produk yang tidak lama seperti perusahaan Spikoe Resep Kuno dan Livana Spiku. Perusahaan Spikoe Resep Kuno dan Livana memiliki daya tahan produk 1 hari dalam suhu ruang lebih lama daripada produk Two Good. Menurut Mariana (2015), kualitas produk merupakan faktor persaingan utama dalam menentukan keberhasilan dan kelangsungan dari suatu perusahaan. Selain itu, persaingan harga dan penetapan harga merupakan hal penting bagi penjual. Terkait dengan aspek kualitas produk, Two Good menggunakan bahan baku grade $A$ agar rasa dan mutu terjaga.

Selanjutnya selain harga dan kualitas produk, sebanyak 15 responden memilih variabel citra merek dalam membeli produk kompetitor. Sebanyak 13 dari 15 responden memilih produk Spikoe Resep Kuno. Sebanyak 2 dari 15 responden memilih produk Livana Spiku. Hal ini menunjukkan bahwa produk Spikoe Resep Kuno dan Livana Spiku memiliki citra merek yang menarik yang diminati oleh masyarakat kota Surabaya. Produk Spikoe Resep Kuno dan Livana Spiku dapat menjadi acuan bagi penelitian dalam mempelajari faktor-faktor yang dapat membuat citra merek yang dapat menarik minat beli konsumen. 
Keller (2013) juga menyebutkan terdapat beberapa kriteria dalam pemilihan merek. Yaitu memorable (mudah diingat), meaningful (memiliki makna), likeable (dapat disukai), transferable (dapat ditransferkan), adaptable (mudah beradaptasi), protectable (dapat dilind ungi).

Perusahaan Two Good belum memiliki citra merek yang mudah diingat, dapat disukai, dapat ditransferkan, mudah beradaptasi dan dapat dilindungi. Sementara perusahaan Spikoe Resep Kuno dan Livana Spiku sudah memiliki citra merek yang mudah diingat, dapat disukai, dapat ditransferkan, mudah beradaptasi dan dapat dilindungi. Menurut Mirabi (2015), pelanggan setia terhadap merek, melakukan pembelian kembali dan merekomendasikan merek kepada orang lain.

Menurut survei terhadap terhadap 15 responden, perusahaan menemukan tiga variabel dari produk kompetitor perusahaan, yaitu harga, kualitas produk dan citra merek yang dapat menjadi faktor-faktor dalam menarik minat beli konsumen. Perusahaan kemudian melakukan survei terhadap 10 calon konsumen mengenai minat beli mereka terhadap produk spiku dari Two Good Bakery tetapi sudah pernah membeli spiku merek kompetitor.

Responden dalam survei ini dari berbagai macam profesi, dengan status sudah menikah belum menikah. Sebelum mereka ditanyakan sebuah pertanyaan, mereka terlebih dahulu dijelaskan tentang bisnis spiku milik Two Good Bakery. Pertanyaan yang diutarakan dalam survei ini adalah "Apakah Anda berminat untuk membeli produk spiku dari Two Good?".

Hasilnya, perusahaan mendapati adanya 7 (tujuh) respon ketidakpastian dalam membeli dari 10 (sepuluh) dari calon konsumen Two Good. Bahkan salah satu narasumber 1 memutuskan untuk tidak melakukan pembelian secara terus-menerus apabila rasa produk benar-benar tidak cocok dan tidak disukai oleh pihak keluarganya juga. Minat beli konsumen sangat dipengaruhi oleh berbagai faktor seperti harga, kualitas produk dan citra merek.

\section{Rumusan Penelitian}

Berdasarkan latar belakang diatas, maka rumusan masalah dalam penelitian ini adalah sebagai berikut.

1. Apakah harga berpengaruh secara signifikan terhadap minat beli calon konsumen Two Good?

2. Apakah kualitas produk berpengaruh secara signifikan terhadap minat beli calon konsumen Two Good?

3. Apakah citra merek berpengaruh secara signifikan terhadap minat beli calon konsumen Two Good?

\section{Tujuan Penelitian}

Berdasarkan rumusan masalah diatas, maka tujuan dalam penelitian ini adalah sebagai berikut.

1. Untuk mengetahui pengaruh harga terhadap minat beli konsumen Two Good.

2. Untuk mengetahui pengaruh kualitas produk terhadap minat beli konsumen Two Good.

3. Untuk mengetahui pengaruh citra merek terhadap minat beli konsumen Two Good. 


\section{KAJIAN PUSTAKA \\ Pengertian Harga}

Menurut Tjiptono \& \& Chandra (2012), secara sederhana harga bisa diartikan sebagai jumlah uang (satuan moneter) dan/atau aspek lain (non-moneter) yang mengandung kegunaaan tertentu yang diperlukan untuk mendapatkan sebuah produk. Menurut Ong \& Sugiharto (2013), indikator dari harga antara lain adalah:

1. Harga yang terjangkau oleh daya beli konsumen.

2. Harga memiliki daya saing dengan harga produk lain.

3. Kesesuaian harga dengan kualitas produk.

Indikator yang mencirikan harga menurut Kotler dalam Rezki (2014), yaitu:

1. Keterjangkauan harga.

2. Kesesuaian harga dengan kualitas produk.

3. Daya saing harga.

4. Ekspetasi terhadap harga.

5. Harga mempengaruhi daya beli konsumen.

Menurut Swastha dan Irawan (2002) dalam Muhammad (2016), mendefinisikan harga adalah jumlah uang (ditambah beberapa produk kalau mungkin) yang dibutuhkan untuk mendapatkan sejumlah kombinasi dari produk dan pelayanannya. Menurut Kotler and Armstrong (2003) dalam Muhammad (2016), harga adalah jumlah semua nilai yang konsumen tukarkan dalam rangka mendapatkan manfaat (dari) memiliki atau menggunakan barang atau jasa.

Menurut Nasution dan Yasin (2014), terdapat indikator-indikator mengenai harga yang dapat memengaruhi minat beli konsumen, yaitu:

1. Penilian mengenai harga secara keseluruhan

2. Respon terhadap kenaikan harga

3. Harga produk tertentu dibandingkan kompetitor

Menurut Amrullah (2016), indikator-indikator harga adalah:

1. Keterjangkauan harga, yaitu harga yang ditawarkan sesuai dengan daya beli konsumen

2. Kesesuaian harga dengan kualitas produk, yaitu harga yang ditawarkan kepada konsumen sesuai dengan kualitas dari produk yang dijual

3. Daya saing harga, yaitu harga yang ditawarkan tidak berbeda jauh dengan harga kompetitor

4. Kesesuaian harga dengan manfaat, yaitu harga yang ditawarkan kepada konsumen sesuai dengan manfaat produk yang dirasakan konsumen.

\section{Kualitas Produk}

Kualitas merupakan hal penting yang harus diusahakan oleh setiap perusahaan agar produk yang dihasilkan dapat bersaing di pasar. Menurut Kasali et al. (2010), produk adalah apa saja baik itu berupa barang, jasa, maupun gagasan yang ditawarkan ke pasar untuk diperoleh, digunakan, atau dikonsumsi yang dapat memenuhi kebutuhan konsumen. Garvin (1984) dalam Asmayadi dan Hartini (2015) menyebutkan delapan dimensi kualitas sebagai kerangka berpikir terkait elemen dasar tapi kualitas produk. Berikut adalah delapan dimensi kualitas yang diperkenalkan oleh Garvin: 
1. Kinerja (performance), yaitu dimensi ini berkaitan dengan seberapa baik suatu produk menjalankan apa yang memang harus dilakukannya dan mengarah kepada karakter produk inti yang meliputi merek, atribut-atribut yang dapat diukur dan aspek-aspek kinerja dan karakteristik pengoperasiannya.

2. Fitur (features), yaitu dimenasi ini berkaitan dengan atribut-atribut tambahan yang melengkapi atau meningkatkan fungsi produk inti.

3. Kesesuaian (comformance), yaitu dimensi ini berkaitan dengan seberapa baik produk tersebut sesuai dengan standar dalam industrinya.

4. Reliabilitas (reliability), yaitu dimensi ini berkaitan dengan kemapuan produk untuk bertahan selama penggunaan yang biasa atau dari kemungkinan mengalami keadaan mal fungsi pada suatu periode tertentu.

5. Daya tahan (durability), yaitu dimensi ini sebagai ukuran ketahanan suatu produk meliputi segi ekonomis atau teknis..

6. Kemudahan perbaikan (serviceability), yaitu dimensi ini sebagai kecepatan, komptensi dan kemudahan perbaikan sebuah produk.

7. Keindahan (aesthetics), yaitu dimensi ini berkaitan dengan bagaimana produk dilihat, dirasakan dan didengar.

8. Persepsi terhadap kualitas (perceived quality), yaitu dimensi ini mencakup kategori reputasi merek termasuk pengaruh citra merek dan faktor-faktor tidak berwujud lainnya yang dapat mempengaruhi persepsi konsumen terhadap kualitas.

Menurut Alfred (2013), dimensi kualitas yang diperkenalkan oleh Garvin merupakan gambaran untuk mewakili keseluruhan penilaian kualitas produk. Gambaran dimensi kualitas mencakup tujuan dan fitur kualitas secara subjektif. Secara khusus dalam menentukan kualitas produk di bidang makanan, ada beberapa indikator yang lebih spesifik. Menurut Setianingsih (2014), kualitas produk mencerminkan kemampuan produk untuk menjalankan tugasnya yang mencakup daya tahan, keandalan atau kemajuan, kekuatan, kemudahan dalam pengemasan dan reparasi produk dan ciri-ciri lainnya.

Menurut Putro (2014), pandangan dibagi menjadi sebagai berikut:

1. Produk yang ditawarkan memiliki karakter.

2. Produk yang dijual memiliki berbagai varian rasa.

3. Produk yang dijual jarang bermasalah.

4. Produk memiliki packaging yang praktis.

5. Produk memiliki daya tahan yang cukup lama.

6. Penanganan keluhan memuaskan.

7. Produk memiliki aroma yang sedap.

\section{Citra Merek}

Citra merek adalah persepsi atau tanggapan dari masyarakat terhadap perusahaan atau pun produk dari perusahaan tersebut. Citra merek dapat dipengaruhi oleh banyak faktor yang di luat kontrol perusahaan. Menurut Kotler dan Armstrong (2016), citra merek adalah persepi konsumen terhadap perusahaan atau produknya yang harus ditanamkan di dalam pikiran pelanggan tidak hanya melalui suatu media, melainkan melalui tiap sarana komunikasi yang tersedia, sehingga citra sangatlah sulit untuk suatu perusahaan dapat menarik dan diingat oleh pelanggan baru untuk membeli 
produk dari perusahaan tersebut dan mempertahankan pelanggan yang sudah ada. Citra merek dapat membuat pelanggan mengetahui dan mengenal suatu produk, mengevaluasi kualitas dari suatu produk tersebut, dan dapat menyebabkan resiko pembelian yang rendah.

Menurut Biel dalam Xian (2011), citra merek terdiri dari 3 (tiga) komponen, yaitu:

1. Citra perusahaan, yaitu citra yang ada di dalam perusahaan itu sendiri. Perusahaan sebagai organisasi berusaha membangun citranya dengan tujuan tak lain agar nama perusahaan tersebut baik di mata konsumen.

2. Citra produk/ konsumen, yaitu citra konsumen terhadap suatu produk yang dapat berdampak positif maupun negatif yang berkaitan dengan kebutuhan, keinginan dan harapan konsumen.

3. Citra pemakai, yaitu dapat dibentuk dari pengalaman dan kontak dengan penggunaan dari suatu produk tersebut oleh konsumen.

Merek adalah nama dan simbol. Ini adalah alat yang sangat penting untuk menciptakan citra positif pada pelanggan. Merek memiliki peran sangat penting dalam menciptakan loyalitas pelanggan dan mempertahankan pangsa pasar perusahaan. Menurut Mirabi (2015), pelanggan yang setia terhadap merek melakukan pembelian kembali dan merekomendasikan merek kepada orang lain. Hasugian (2015) mengatakan, merek memiliki manfaat bagi produsen dan konsumen. Keller (2013) juga menyebutkan terdapat beberapa kriteria di dalam pemilihan elemen merek, antara lain:

1. Memorable (mudah diingat), yaitu suatu kondisi yang diperlukan dalam membangun citra merek untuk mencapai tingkat kesadaran merek yang tinggi

2. Meaningful (memiliki makna), yaitu elemen merek hendaknya memiliki suatu makna, baik dengan konten deskriptif atau persuasif.

3. Likeable (dapat disukai), yaitu suatu keadaan di mana konsumen biasanya akan mencari suatu merek yang dapat menarik perhatian, yang mana merek tersebut dapat disukai baik secara visual, verbal dan dengan cara yang lainnya.

4. Transferable (dapat ditransferkan), yaitu sebuah elemen yang merek yang dapat dipindahkan dari pikiran konsumen satu dengan konsumen yang lainnya.

5. Adaptable (mudah beradaptasi), yaitu suatu keadaan yang menyebabkan sebuah merek diharuskan memiliki adanya elemen yang dapat berbaur dan mudah beradaptasi, agar sebuah merek memiliki kemampuan bertahan dan mudah diperbaharui.

6. Protectable (dapat dilindungi), yaitu berkaitan elemen merek yang dapat dilindungi baik dalam hukum maupun dalam persaingan.

\section{Minat Beli}

Menurut Cronin et al. dalam Pratama (2014), minat beli adalah perilaku pelanggan di mana pelanggan merespon positif terhadap kualitas produk atau jasa dari suatu perusahaan dan berniat mengkonsumsi kembali produk perusahaan tersebut. Menurut Ferdinand dalam Adji \& Semuel (2014), minat beli dapat diidentifikasikan melaui indikator-indikator sebagai berikut: 
1. Minat transaksional, yaitu kecenderungan seseorang untuk mebeli produk.

2. Minat referensial, yaitu kecenderungan seseorang untuk mereferensikan produk kepada orang lain.

3. Minat preferensial adalah minat yang menggambarkan perilaku seseorang yang memiliki preferensi utama pada produk tersebut. Preferensi ini hanya dapat diganti jika terjadi sesuatu dengan produk preferensinya.

4. Minat eksploratif adalah minat yang menggambarkan perilaku seseorang yang selalu mencari informasi mengenai produk yang diminatinya dan mencari informasi untuk mendukung sifat-sifat positif dari produk tersebut.

Menurut Suwandari (2008) dalam Nasution dan Yasin (2014), yang menjadi indikator minat beli seorang calon konsumen adalah:

1. Attention, yaitu perhatian calon konsumen terhadap produk yang ditawarkan oleh produsen.

2. Interest, yaitu ketertarikan calon konsumen terhadap produk yang ditawarkan oleh produsen.

3. Desire, yaitu keinginan calon konsumen untuk memiliki produk yang ditawarkan oleh produsen.

4. Action, yaitu calon konsumen melakukan pembelian terhadap produk yang ditawarkan.

\section{METODE PENELITIAN}

Jenis Penelitian

Penelitian ini merupakan penelitian kuantitatif. Menurut Bungin (2014), penelitian kuantitatif adalah pendekatan untuk menguji teori obyektif dengan memeriksa hubungan antarvariabel. Variabel kemudian dapat diukur, diproses, dan dianalisis sehingga dapat mengetahui kebenaran hasil penelitian. Penelitian melibatkan proses sistematis dan objektif, target pasar sebagai sampel dan tanggapan diukur menggunakan teknik pengumpulan data terstruktur.

\section{Populasi dan Sampel}

Menurut Sugiyono (2013), populasi adalah wilayah generalisasi yang terdiri atas obyek atau subyek yang mempunyai kualitas dan karakteristik tertentu yang ditetapkan untuk dipelajari dan kemudian ditarik kesimpulannya. Populasi yang digunakan untuk penelitian ini adalah penduduk yang memiliki tempat tinggal di Pakuwon City di kota Surabaya. Jumlah dari populasi yang akan digunakan adalah diketahui 4.000 orang dengan rentang usia kisaran 16-55 tahun. Populasi ini digunakan karena karakteristik calon pembeli sesuai dengan target pasar yang dituju oleh perusahaan.

Teknik purposive sampling dalam penelitian ini. Menurut Sugiyono (2013), teknik purposive sampling merupakan metode yang menggunakan kriteria yang telah ditetapkan terlebih dahulu. Kriteria sampel yang digunakan pada penelitian ini adalah:

1. Calon konsumen yang berdomisili di Pakuwon City Surabaya.

2. Sudah pernah membeli spiku merek kompetitor lain dalam jangka waktu 1 (satu) bulan terakhir

3. Belum pernah membeli produk Two Good 
4. Memiliki kisaran umur 16-55 tahun

Penelitian ini ditetapkan dengan batas toleransi kesalahan sebesar $10 \%$ supaya jawaban yang diberikan untuk penelitian ini memiliki tingkat akurasi sebesar $90 \%$. Penentuan jumlah sampel menggunakan Rumus Slovin sebagai berikut:

$$
\mathrm{n}=\frac{\mathrm{N}}{1+\mathrm{N}(\mathrm{e})^{2}}
$$

Keterangan:

$\mathrm{n}=$ ukuran sampel

$\mathrm{N}=$ ukuran populasi $=4,000$

$\mathrm{e}=$ batas toleransi kesalahan (error tolerance)

$\mathrm{n}=\frac{\mathrm{N}}{1+\mathrm{N}(\mathrm{e})^{2}}$

$\mathrm{n}=\frac{4,000}{1+4,000(0,10)^{2}}$

$\mathrm{n}=97,56$

$\mathrm{n}=98$ sampel

\section{Tempat dan Waktu Penelitian}

Tempat yang digunakan sebagai lokasi penelitian dan lokasi penggalian data penelitian adalah daerah Pakuwon City Surabaya. Penelitian ini dilaksanakan di tahun 2020. Waktu penelitan yang dituju adalah saat penduduk Pakuwon City sedang beraktivitas di luar rumah, ruko atau apartemen, seperti mencuci mobil, jalan bersama dengan anjing, jalan sehat dan sebagainya. Aktivitas pencarian data dalam penelitian ini akan diawali dengan mengunjungi penduduk yang merupakan calon konsumen Two di daerah Pakuwon City, kemudian dipresentasikan tentang produk yang akan dikeluarkan oleh Two Good serta diberikan tester produknya dan akan dimintai orang tersebut untuk menjadi responden dengan mengisi kuesioner penelitian secara tertulis.

\section{Analisis Regresi Berganda}

Analisis data utama dalam penelitian ini menggunakan regresi berganda. Menurut Priyatno (2013), analisis ini untuk melihat hubungan atau pengaruh dari satu variabel dependen dengan lebih dari satu variabel. Persamaan regresi linear berganda dalam penelitian adalah sebagai berikut:

$$
\mathrm{Y}=\alpha+\beta_{1} \mathrm{X}_{1}+\beta_{2} \mathrm{X}_{2}+\beta_{3} \mathrm{X}_{3}+\varepsilon
$$

Keterangan:

Y: Variabel terikat (minat beli)

A: Konstanta

$\beta_{1}$ : Koefisien regresi Harga

$\beta_{2}$ : Koefisien regresi Kualitas Produk

$\beta_{3}$ : Koefisien regresi Citra Merek

$\mathrm{X}_{1}$ : Harga

$\mathrm{X}_{2}$ : Kualitas Produk

$\mathrm{X}_{3}$ : Citra Merek

ع: Error atau residual 


\section{HASIL PENELITIAN DAN PEMBAHASAN \\ Profil Objek Penelitian}

Perusahaan Two Good berbasis online dan bergerak di bidang makanan dengan produk berupa spiku. Perusahaan ini mulai berdiri pada bulan Januari 2018. Perusahaan Two Good berdiri karena melihat adanya peluang yang besar dalam industri makanan di Jawa Timur. Selain itu, perusahaan Two Good ingin memberikan diferensiasi dalam industri makanan spiku dengan berbagai inovasi dalam segi isi, rasa dan penyajiannya. Perusahaan Two Good menghadirkan 4 (empat) rasa, yaitu original, coklat, keju dan teh hijau. 4 (empat) menu ini disajikan melalui ukuran 20 x $20 \mathrm{~cm}$ dengan harga jual produk sebesar Rp 100.000 per kotak. Target pasar dari Two Good sendiri adalah penduduk Surabaya yang berusia 16-55 tahun yang berasal dari kelas menengah ke atas. Two Good berencana ke depannya akan membuka ruko di daerah Pakuwon City, lebih tepatnya di daerah ruko San Diego.

Karakteristik responden penelitian ini diketahui dari 98 responden, sebanyak 59 responden $(60,2 \%)$ berjenis kelamin pria dan sisanya sebanyak 39 responden $(39,8 \%)$ berjenis kelamin wanita. Sedangkan berdasarkan usia responden diketahui sebanyak 27 responden $(27,6 \%)$ berusia $16-25$ tahun, 35 responden $(35,7 \%)$ berusia $26-35$ tahun, 22 responden $(22,4 \%)$ berusia $36-45$ tahun dan 14 responden $(14,3 \%)$ berusia $46-55$ tahun.

\section{Hasil Analisis Regresi Berganda}

Analisis dalam penelitian ini menggunakan variabel bebas $\mathrm{X}_{1}$ (Harga), $\mathrm{X}_{2}$ (Kualitas Produk) dan $\mathrm{X}_{3}$ (Citra Merek). Sedangkan untuk variabel terikatnya adalah $\mathrm{Y}$ (Minat Beli). Agar dapat mengetahui hubungan antara variabel bebas $\mathrm{X}_{1}$ (Harga), $\mathrm{X}_{2}$ (Kualitas Produk) dan $\mathrm{X}_{3}$ (Citra Merek) sebagai variabel independen berhubungan positif atau negatif, maka dilakukan analisis regresi berganda.

Tabel 1. Hasil Pengujian Regresi Linier Berganda

\section{Coefficients $^{\mathbf{a}}$}

\begin{tabular}{|c|c|c|c|c|c|c|}
\hline \multirow{2}{*}{\multicolumn{2}{|c|}{ Model }} & \multicolumn{2}{|c|}{$\begin{array}{c}\text { Unstandardized } \\
\text { Coefficients }\end{array}$} & \multirow{2}{*}{$\begin{array}{c}\begin{array}{c}\text { Standardized } \\
\text { Coefficients }\end{array} \\
\text { Beta } \\
\end{array}$} & \multirow[b]{2}{*}{$\mathrm{t}$} & \multirow[b]{2}{*}{ Sig. } \\
\hline & & $\mathrm{B}$ & Std. Error & & & \\
\hline \multirow[t]{4}{*}{1} & (Constant) & 4,622 & 1,754 & & 2,635 &, 010 \\
\hline & Harga & ,616 &, 080 & ,633 & 7,697 & ,000 \\
\hline & $\begin{array}{l}\text { Kualitas } \\
\text { Produk }\end{array}$ & , 130 &, 065 &, 178 & 2,011 & ,047 \\
\hline & Citra Merek &,- 074 & ,096 &,- 070 &,- 769 & ,444 \\
\hline
\end{tabular}

a. Dependent Variable: Minat Beli

Sumber: Hasil Penelitian, diolah (2020)

Berdasarkan Tabel 1 dapat diketahui persamaan regresi yang digunakan pada penelitian ini adalah:

$\mathrm{Y}=4,622+0,616 \mathrm{X}_{1}+0,130 \mathrm{X}_{2}-0,074 \mathrm{X}_{3}$

Keterangan:

$\mathrm{Y}=$ Minat Beli

$\mathrm{X}_{1}=$ Harga 
$\mathrm{X}_{2}=$ Kualitas produk

$\mathrm{X}_{3}=$ Citra Merek

Interpretasi terhadap persamaan berdasarkan analisis nilai koefisien regresi adalah:

1. Nilai koefisien $X_{1}$ (Harga) bernilai positif sebesar 0,616 , dengan nilai sig. $\leq 0,05$ sehingga dapat disimpulkan variabel $\mathrm{X}_{1}$ (Harga) berpengaruh signifikan terhadap $\mathrm{Y}$ (Minat Beli).

2. Nilai koefisien $X_{2}$ (Kualitas Produk) bernilai positif sebesar 0,130 , dengan nilai sig. $\leq 0,05$ sehingga dapat disimpulkan variabel $\mathrm{X}_{2}$ (Kualitas Produk) berpengaruh signifikan terhadap Y (Minat Beli).

3. Nilai koefisien $\mathrm{X}_{3}$ (Citra Merek) bernilai negatif sebesar 0,074, tetapi nilai sig. > 0,05 sehingga dapat disimpulkan variabel $\mathrm{X}_{3}$ (Citra Merek) tidak berpengaruh signifikan terhadap Y (Minat Beli).

\section{Uji F}

Uji $F$ bertujuan untuk melihat pengaruh seluruh variabel bebas secara simultan terhadap variabel terikat. Dalam penelitian ini digunakan tingkat signifikansi sebesar 0,05. Jika hasil Uji $F$ menunjukkan nilai probabilitas $\leq 0,05$, maka dapat disimpulkan terdapat pengaruh yang signifikan secara simultan antara variabel bebas terhadap variabel terikat. Namun apabila nilai probabilitas $>0,05$, itu berarti tidak terdapat pengaruh yang signifikan secara simultan antara variabel bebas terhadap variabel terikatnya.

Tabel 2. ANOVAa

\begin{tabular}{|c|c|c|c|c|c|c|}
\hline \multicolumn{2}{|c|}{ Model } & $\begin{array}{l}\text { Sum of } \\
\text { Squares }\end{array}$ & df & Mean Square & $\mathrm{F}$ & Sig. \\
\hline \multirow[t]{3}{*}{1} & Regression & 131,935 & 3 & 43,978 & 25,566 &, $000^{\mathrm{b}}$ \\
\hline & Residual & 161,698 & 94 & 1,720 & & \\
\hline & Total & 293,633 & 97 & & & \\
\hline
\end{tabular}

a. Dependent Variable: Minat Beli

b. Predictors: (Constant), Citra Merek, Harga, Kualitas Produk

Sumber: Hasil Penelitian, diolah (2020)

Berdasarkan Tabel 2 diketahui nilai $\mathrm{F}$ sebesar 25,566 dan nilai sig. sebesar 0,000. Dikarenakan nilai sig. $\leq 0,05$ sehingga dapat disimpulkan terdapat pengaruh signifikan secara simultan antara variabel bebas terhadap variabel terikat. Dengan kata lain variabel $\mathrm{X}_{1}$ (Harga), $\mathrm{X}_{2}$ (Kualitas Produk) dan $\mathrm{X}_{3}$ (Citra Merek) secara simultan berpengaruh signifikan terhadap variabel $\mathrm{Y}$ (Minat Beli).

\section{Uji t}

Uji t atau Uji Parsial bertujuan untuk melihat pengaruh variabel bebas secara parsial terhadap variabel terikat. Dalam penelitian ini, tingkat signifikansi yang digunakan sebesar 0,05. Hasil Uji t dapat dilihat pada kolom coefficients pada kolom sig (significance). Apabla probabilitas nilai $\mathrm{t}$ atau signifikansi $\leq 0,05$, maka dapat disimpulkan bahwa terdapat pengaruh variabel bebas terhadap variabel terikat secara parsial. Namun, apabila probabilitas nilai $\mathrm{t}$ atau signifikansi $>0,05$, maka dapat 
disimpulkan bahwa tidak terdapat pengaruh variabel bebas terhadap variabel terikat secara parsial.

Tabel 3. Hasil Uji $\mathrm{t}$

\begin{tabular}{|c|c|c|c|}
\hline Variabel & Koefisien & Signifikan & Kesimpulan \\
\hline $\mathbf{X}_{\mathbf{1}}$ & 0,616 & 0,000 & H1 diterima \\
\hline $\mathbf{X}_{\mathbf{2}}$ & 0,130 & 0,047 & H2 diterima \\
\hline $\mathbf{X}_{\mathbf{3}}$ & $-0,074$ & 0,444 & H3 ditolak \\
\hline
\end{tabular}

Sumber: Hasil Penelitian, diolah (2020)

Dari Tabel 3 terlihat nilai sig pada variabel $\mathrm{X}_{3}$ (Citra Merek) > 0,05, maka dapat disimpulkan $\mathrm{X}_{3}$ (Citra Merek) tidak berpengaruh signifikan terhadap variabel $\mathrm{Y}$ (Minat Beli) secara parsial. Sementara variabel $\mathrm{X}_{1}$ (Harga) dan $\mathrm{X}_{2}$ (Kualitas Produk) berpengaruh signifikan secara parsial terhadap variabel Y (Citra Merek) dikarenakan nilai sig. $\leq 0,05$.

\section{Koefisien Determinasi}

Uji koefisien determinasi untuk menentukan prediksi seberapa besar kontribusi variabel terikat (Minat Beli) yang diterangkan oleh variabel bebas (Harga, Kualitas Produk dan Citra Merek) dengan syarat hasil Uji $\mathrm{F}$ dalam analisis regresi bernilai signifikan.

Tabel 4. Koefisien Determinasi $\left(\mathbf{R}^{2}\right)$ dan Koefisien Korelasi $(\mathbf{R})$ Model Summary

\begin{tabular}{|l|r|r|r|r|}
\hline Model & $\mathrm{R}$ & R Square & $\begin{array}{c}\text { Adjusted R } \\
\text { Square }\end{array}$ & $\begin{array}{l}\text { Std. Error of } \\
\text { the Estimate }\end{array}$ \\
\hline 1 &, $670^{\mathrm{a}}$ &, 449 &, 432 & 1,312 \\
\hline
\end{tabular}

a. Predictors: (Constant), Citra Merek, Harga, Kualitas

Produk

Sumber: Hasil Penelitian, diolah (2020)

Dalam Tabel 4 menunjukkan nilai koefisien korelasi (R) sebesar 0,670, dapat disimpulkan terdapat hubungan yang kuat antara variabel $\mathrm{X}_{1}$ (Harga), $\mathrm{X}_{2}$ (Kualitas Produk) dan $\mathrm{X}_{3}$ (Citra Merek) terhadap Minat Beli (Y). R Square sebesar 0,449 atau $44,9 \%$, dapat disimpulkan variabel terikat (Minat Beli) yang diterangkan oleh variabel bebasnya (Harga, Kualitas Produk dan Citra Merek) sebesar 44,9\%. Sedangkan sebanyak $55,1 \%$ diterangkan oleh variabel bebas lainnya selain Harga, Kualitas Produk dan Citra Merek.

\section{Pembahasan}

\section{Pengaruh Harga terhadap Minat Beli}

Berdasarkan hasil uji t diketahui variabel Harga $\left(\mathrm{X}_{1}\right)$ berpengaruh signifikan terhadap variabel Minat Beli (Y). Hasil uji t menunjukkan nilai sig. pada variabel Harga $\left(\mathrm{X}_{1}\right)$ sebesar 0,000 sesuai dengan ketentuan nilai signifikansi $\leq 0,05$, maka bisa disimpulkan variabel Harga $\left(\mathrm{X}_{1}\right)$ berpengaruh secara signifikan secara parsial terhadap variabel Minat Beli (Y). Nilai $\mathrm{t}$ hitung yang positif menunjukkan variabel Harga mempunyai pengaruh yang searah terhadap variabel Minat Beli. 
Hasil pengujian hipotesis Kolopita dan Soegoto (2015) menemukan variabel harga dalam penelitian ini memiliki pengaruh yang signifikan terhadap minat beli khususnya pada responden di PT. Sinar Galesong cabang Manado, dan pengaruh dari variabel harga terhadap minat beli konsumen adalah signifikan.

Harga yang ditetapkan Two Good sesuai dengan kualitas produk. Kualitas produk yang dimaksud dalam penelitian ini adalah apakah produk Two Good termasuk spiku dengan bahan baku yang baik ketika dikonsumsi secara langsung atau tidak langsung. Pertanyaan penelitian berangkat dari asumsi calon konsumen belum menemukan kualitas produk ketika mendengarkan presentasi mengenai spesifikasi produk dan mencoba produk secara langsung. Kemungkinan pada saat presentasi pihakTwo Good belum memberikan informasi apakah bahan yang digunakan memiliki kualitas bahan yang baik atau tidak. Hal ini membuat calon konsumen belum merasa yakin dengan produk Two Good, sehingga item pertanyaan ini dengan nilai terendah.

Two Good mengatasi hal itu dengan meminta saran dan kritik mengenai harga dan kualitas produk untuk menjadi masukan bagi Two Good. Selain itu membuat foto produk yang menunjukkan kualitas bahan sehingga produk terlihat lebih meyakinkan kualitasnya. Foto yang berisi testimoni konsumen sehingga membuat calon konsumen lebih yakin Two Good memiliki kualitas produk yang baik.

Hasil kuesioner menunjukkan harga yang ditetapkan Two Good lebih bagus daripada produk kompetitor. Hal ini karena semua responden pada penelitian sudah memiliki pengalaman dalam menemukan produk yang bermanfaat dari produk kompetitor. Two Good perlu untuk melakukan uji coba lagi agar mengeluarkan produk dengan manfaat yang lebih baik dari produk kompetitor sehingga dapat menjangkau lebih banyak calon konsumen dari berbagai kalangan usia di Pakuwon City. Harga sangat berpengaruh terhadap minat beli calon konsumen. Hal ini terlihat pada calon konsumen yang masih ragu dengan harga yang ditetapkan dengan kualitas produk dan manfaat produk. Two Good perlu memperbaiki kualitas produk dan manfaat yang terkandung dalam produk sehingga harga dapat diterima calon konsumen.

Koefisien harga yang positif juga menyatakan semakin besar investasi perusahaan untuk harga, maka semakin naik minat beli calon konsumen terhadap produk Two Good. Jika perusahaan berinvestasi dalam harga seperti menaikkan harga jual produk, maka waktu, tenaga dan biaya yang dikeluarkan tidak akan sia-sia karena calon konsumen akan tertarik untuk membeli. Semakin sedikit investasi perusahaan dalam harga, maka minat beli calon konsumen akan semakin menurun karenaharga tidak akan semakin dipercaya dan tidak diminati calon konsumen. Dalam minat beli, calon konsumen melihat faktor harga sebagai faktor utama sebelum membeli sebuah produk.

\section{Pengaruh Kualitas Produk terhadap Minat Beli}

Berdasarkan hasil uji $\mathrm{t}$ diketahui variabel Kualitas Produk $\left(\mathrm{X}_{2}\right)$ berpengaruh terhadap variabel Minat Beli (Y). Variabel Kualitas Produk $\left(\mathrm{X}_{2}\right)$, berdasarkan hasil uji, terlihat nilai sig. variabel Kualitas Produk adalah 0,045 sesuai dengan ketentuan nilai signifikansi $\leq 0,05$, maka dapat disimpulkan variabel Kualitas Produk $\left(\mathrm{X}_{2}\right)$ berpengaruh secara parsial terhadap variabel minat beli (Y). Nilai t hitung yang positif menunjukkan variabel Kualitas Produk $\left(\mathrm{X}_{2}\right)$ mempunyai pengaruh yang searah 
terhadap variabel Minat Beli (Y). Temuan ini dapat membuktikan hasil dari penelitian Prasetyo dan Purwantini (2017) bahwa kualitas produk berpengaruh positif terhadap minat beli konsumen. Hasil penelitian Prasetyo dan Purwantini (2017) menunjukkan minat beli konsumen akan meningkat apabila kualitas produk meningkat. Temuan ini juga mendukung hasil penelitian Himawan (2016) yang menyatakan kualitas produk berpengaruh positif dan signifikan terhadap minat beli notebook Acer. Hermanto dan Cahyadi (2015) juga menemukan kualitas produk $\left(\mathrm{X}_{1}\right)$ memiliki pengaruh signifikan secara parsial terhadap minat beli ulang (Y).

Hasil kuesioner menunjukkan calon konsumen tidak ragu terhadap produk Two Good memiliki warna dan rasa yang khas. Hal ini karena calon konsumen memiliki pengalaman dalam melihat dan merasakan produk yang lebih memiliki warna dan rasa yang khas sehingga beberapa calon konsumen tidak melihat dan merasakan warna dan rasa yang khas dari Two Good pada saat presentasi dan mencoba produk. Calon konsumen juga belum yakin produk Two Good dapat tahan lama. Hal itu karena produk Two Good hanya tahan 4 hari di dalam suhu ruangan. Berbeda dengan produk kompetitor yang rata-rata dapat tahan lama selama 5 hari di dalam suhu ruangan. Aspek yang perlu dievaluasi adalah warna dan rasa yang khas serta daya tahan produk. Two Good masih belum menemukan diferensiasi warna dan rasa spiku dari kompetitor selama uji coba produk sampai sekarang. Two Good juga masih belum menemukan cara agar produk dapat memiliki daya tahan lebih lama tanpa mengurangi kualitas produk yang disajikan. Two Good mendapati dengan memasukkan produk dalam kulkas dapat membuat daya tahan produk jauh lebih lama. Suhu yang rendah dapat menjaga kualitas produk lebih baik. Cara ini dilakukan Two Good dalam menjaga kualitas produk sebelum sampai ke tangan konsumen. Namun jika produk sudah sampai ke tangan konsumen dan tidak segera dimasukkan kulkas langsung maka daya tahan produk menurun seiring dengan suhu ruangan. Two Good membutuhkan saran dan kritik mengenai warna dan rasa dari calon konsumen serta belum pernah diberikan kompetitor untuk calon konsumen dari berbagai kalangan usia agar dapat menjadi masukan bagi Two Good. Two Good juga perlu mencantumkan label pada kemasan bahwa produk jauh lebih tahan lama jika dimasukkan ke dalam kulkas agar konsumen dapat menikmati produk jauh lebih lama dengan kualitas produk yang tidak turun secara drastis.

Koefisien kualitas produk yang positif juga menyatakan semakin besar investasi yang dilakukan perusahaan untuk kualitas produk, maka semakin meningkat minat beli calon konsumen terhadap produk Two Good. Jika perusahaan berinvestasi dalam kualitas produk seperti menggunakan bahan baku dari luar negeri, maka waktu, tenaga dan biaya yang dikeluarkan tidak akan sia-sia karena calon konsumen akan tertarik untuk membeli. Semakin sedikit investasi perusahaan dalam kualitas produk, maka minat beli calon konsumen akan semakin menurun dikarenakan kualitas produk tidak akan semakin dipercaya dan tidak diminati oleh calon konsumen. Hal ini dapat diasumsikan bahwa dalam minat beli, calon konsumen melihat faktor kualitas produk sebagai faktor utama sebelum membeli sebuah produk. 


\section{Pengaruh Citra Merek terhadap Minat Beli}

Berdasarkan hasil uji t diketahui variabel Citra Merek $\left(\mathrm{X}_{3}\right)$ tidak berpengaruh secara signifikan terhadap variabel Minat Beli $(\mathrm{Y})$. Variabel Citra Merek $\left(\mathrm{X}_{3}\right)$ berdasarkan hasil uji, terlihat nilai sig. variabel Citra Merek adalah 0,473 tidak sesuai dengan ketentuan nilai signifikansi $\leq 0,05$, maka dapat disimpulkan variabel Citra Merek $\left(\mathrm{X}_{3}\right)$ tidak berpengaruh secara parsial terhadap variabel Minat Beli (Y). Temuan ini sesuai hasil penelitian Desi (2009) dalam Himawan (2016) bahwa variabel citra merek tidak berpengaruh terhadap variabel minat beli calon konsumen. Arista dan Triastuti (2011) juga menyatakan variabel citra merek $\left(\mathrm{X}_{3}\right)$ tidak memiliki pengaruh signifikan untuk menjadi syarat terhadap variabel minat beli produk Telkom Speedy. Menurut Ende (2017), citra merek tidak berpengaruh signifikan terhadap minat beli smartphone merek Xiaomi. Hal ini berarti calon konsumen memandang masalah citra merek bukan hal utama dalam pertimbangan membeli produk. Terdapat atribut lain yang menjadi faktor utama alasan untuk membeli.

Calon konsumen di Pakuwon City tidak terpengaruh oleh citra merek yang dimiliki Two Good. Hal ini karena citra merek tidak menjadi pertimbangan utama masyarakat dalam membeli produk. Citra merek juga jika ditingkatkan maka tidak akan meningkatkan minat beli calon konsumen secara signfikan. Hal ini karena citra merek kompetitor lain sudah lebih dahulu telah dikenal oleh masyarakat Pakuwon City. Bagi calon konsumen, apapun spiku yang ada, logo, simbol atau istilah apapun sering tidak menjadi persoalan, karena citra merek kompetitor lain sudah terlalu melekat dalam pikiran dan hati konsumen yang loyal. Kemungkinan hasil menjadi tidak signifikan karena calon konsumen belum dapat membedakan pesan merek Two Good dengan merek spiku lainnya. Agar pesan merek Two Good dapat dibedakan dengan spiku lainnya oleh calon pembeli, maka Two Good akan melakukan perbaikan dengan membuat pesan merek yang lebih menarik ke depannya agar tidak terkesan biasa dan memiliki diferensiasi yang lebih mencolok daripada merek spiku lainnya.

Koefisien citra merek yang negatif juga menyatakan semakin besar investasi yang dilakukan perusahaan untuk citra merek, maka semakin turun minat beli calon konsumen terhadap produk Two Good. Jika perusahaan berinvestasi dalam citra merek seperti menggunakan endorser, maka hanya akan membuang waktu, tenaga dan biaya karena calon konsumen tidak akan tertarik untuk membeli. Semakin sedikit investasi perusahaan dalam citra merek, maka minat beli calon konsumen akan semakin meningkat karena citra merek akan semakin dipercaya dan diminati oleh calon konsumen. Di Pakuwon City, terdapat tenant martabak San Fransisco di ruko San Antonio yang mereknya sudah berdiri sejak tahun 1967. Namun melalui wawancara singkat dengan pegawai, dapat disimpulkan popularitas yang dimiliki tidaklah cukup kuat untuk menarik minat beli calon konsumen, bertentangan dengan apa yang dinyatakan oleh Kotler dan Armstrong (2016). Hal ini dapat diasumsikan bahwa dalam minat beli, calon konsumen melihat pertimbangan faktor lain selain citra merek, seperti harga, kualitas produk, kepercayaan merek, dll sebelum membeli sebuah produk. 


\section{KESIMPULAN DAN SARAN \\ Kesimpulan}

Berdasarkan hasil analisa data statistik dan deskriptif, disimpulkan:

1. Variabel $X_{1}$ (Harga) berpengaruh secara signifikan terhadap $Y$ (Minat Beli), sehingga hipotesis pertama $\left(\mathrm{H}_{1}\right)$ diterima.

2. Variabel $\mathrm{X}_{2}$ (Kualitas Produk) berpengaruh secara signfikan terhadap $\mathrm{Y}$ (Minat Beli), sehingga hipotesis kedua $\left(\mathrm{H}_{2}\right)$ diterima.

3. Variabel $\mathrm{X}_{3}$ (Citra Merek) tidak berpengaruh secara signifikan terhadap Y (Minat Beli), sehingga hipotesis ketiga $\left(\mathrm{H}_{3}\right)$ ditolak.

\section{Saran}

1. Bagi Penelitian di Masa Mendatang

a. Penelitian selanjutnya dapat menggunakan variabel yang belum digunakan dalam penelitian ini selain harga, kualitas produk dan citra merek seperti variabel promosi, kualitas pelayanan, persepsi resiko, persepsi harga, atribut produk, lokasi, keberagaman produk, iklan dll sehingga pada hasil penelitian berikutnya dapat digunakan menjadi acuan atau referensi untuk penelitian dalam meneliti minat beli dari calon konsumen terhadap bisnis perusahaan.

b. Penelitian selanjutnya dapat menggunakan variabel yang sama, tetapi menggunakan populasi yang berbeda seperti warga Citraland, Royal Resident, Central Park dan Grand Kenjeran.

c. Hasil penelitian dapat digunakan sebagai acuan teori pada bisnis yang tergolong dalam kategori Food and Beverages.

2. Bagi Two Good

a. Menjaga kenaikan harga jual produk tanpa mengurangi kualitas produk yang terkandung di dalamnya dikarenakan ada pengaruh minat beli dari calon konsumen terhadap kualitas produk yang didapat dari harga jual produk makanan spiku.

b. Mempertahankan kualitas produk dengan melakukan Quality Control terhadap bahan baku yang digunakan dan proses produksi yang sesuai dengan Standard Operating Procedure yang telah ditetapkan dikarenakan ada pengaruh kenaikan minat beli dari calon konsumen terhadap kenaikan kualitas produk makanan spiku yang disajikan, sehingga dapat menjadi acuan atau referensi ketika membuat usaha makanan baru yang berbeda.

\section{DAFTAR PUSTAKA}

Adji, J., \& Semuel, H. 2014. Pengaruh Satisfaction dan Trust Terhadap Minat Beli Konsumen (Purchase Intention) di Starbucks The Square Surabaya. Journal Management Pemasaran Petra, 2, 1-10.

Amrullah, A. R. 2016. Pengaruh Kualitas Produk, Harga dan Citra Merek Terhadap Keputusan Pembelian Honda Beat. Jurnal Ilmu dan Rise Manajemen Vol. 5, No. 7, Juli 2017

Arista, E.D., Astuti, S. R. T. 2011. Analisis Pengaruh Iklan, Brand Trust dan Brand Image Terhadap Minat Beli Konsumen Telkom Speedy di Kota Semarang. Skripsi. Universitas Diponegoro, Semarang. 
Asmayadi, E., Hartini, S. 2015. The Impact of Service Quality and Product Quality Toward Customer Loyalty Through Emotional and Functional values in Traditional Markets in Pontianak, Indonesia. European Journal of Business Management, Vol. 7, No. 5.

Bungin, B. 2014. Metodologi Penelitian Kuantitatif - Edisi Kedua. Jakarta: Kencana Prenada Media Group.

Kolopita, D.A. \& Soegoto, A. S. 2015. Analisis Atribut Produk dan Harga Terhadap Minat Beli Mobil Suzuki Ertiga di Kota Manado. Jurnal EMBA. Vol. 3. No. 2 Juni 2015, Hal. 12-24.

Ende, Kusuma, J.W., 2017. Peran Citra Merek, Persepsi Harga, Persepsi Risiko Terhadap Minat Beli Produk Smartphone Merek Xiaomi. Jurnal Manajemen dan Bisnis. Volume IX. No. 2. Juni 2017.

Garvin, David, A. 1984. Managing Quality. USA: Harvard Business School.

Hasugian, J. T. M. 2015. Pengaruh Brand Image dan Brand Trust Terhadap Brand Loyalty Telkomsel, eJournal Ilmu Administrasi Bisnis, Vol. 3, Issue 4: pp 923-937.

Hermanto, K., Cahyadi, Irvan. 2015. Pengaruh Kualitas Produk dan Harga Terhadap Minat Beli Ulang Fastfood Ayam Goreng Tepung di Kalangan Mahasiswa Universitas Kristen Petra Surabaya. Jurnal Hospitality dan Manajemen Jasa. Vol. 3, No. 2.

Himawan, Adrian. 2016. Pengaruh Kualitas Produk, Citra Merek dan Promosi Terhadap Minat Beli Notebook ACER (Studi Kasus pada mahasiswa Universitas Negeri Yogyakarta).

Kasali, R. 2010. Modul Kewirausahaan. Yayasan Rumah Perubahan, Jakarta.

Keller, Kevin L. 2013. Strategic Brand Management; Building, Measuring, and Managing Brand Equity. Fourth Edition Harlow, English: Pearson Education Inc.

Kotler, P., \& Amstrong, G. 2008. Prinsip-prinsip Pemasaran. Jilid 1 dan 2. Edisi 12, Jakarta: Erlangga.

Kotler, P., Amstrong, G. 2012. Prinsip-prinsip Pemasaran. Edisi 13. Jilid 1. Jakarta: Erlangga.

Kotler, P. \& Amstrong, G. 2014. Prinsip-prinsip Pemasaran. Jakarta: Erlangga.

Kotler, P. \& Armstrong, G. 2016. Marketing Management, $15^{\text {th }}$ Edition. New jersey: Pearson Pretice Hall, Inc.

Kotler, P. \& Kevin, L. K. 2012. Marketing Management Fourteenth Edition. England: Education Limited.

Mariana. 2015. Pengaruh Kualitas Produk dan Harga Terhadap Keputusan Pembelian Produk Pada Industri UKM Amplang UD. Sinar Rejeki Di Samarinda. eJournal Ilmu Administrasi Bisnis, 2015, 3(2): 388-402.

Mirabi, V., Akbariyeh, H., Tahmasebifard, H. 2015. A Study of Factors Affecting on Customers Purchase Intention. Journal of Multidisciplinary Engineering Science and Technology, Vol. 2. Issue, January.

Nasution, M.F.R., \& Hanifa Yasin. 2014. Pengaruh Promosi dan Harga Terhadap Minat Beli Perumahan Obama PT. Nailahadi Kurnia Sei Mencirim Medan. Jurnal Ilmiah Manajemen \& Bisnis. Vol. 14, No. 02, 136-143. 
Ong. I.A., \& Sugiharto, S. 2013. Analisa Pengaruh Strategi Diferensiasi, Citra Merek, Kualitas Produk Dan Harga Terhadap Keputusan Pembelian Pelanggan Di Cincau Station Surabaya. Journal Management Pemasaran, 1, 1-11.

Pratama, Rizky Anugerah. 2014. Analisis Pengaruh Citra Merek, Daya Tarik Iklan, Dan Harga Terhadap Minat Beli Smartphone Nokia Lumia (Studi Pada Konsumen Smartphone di Kota Semarang)". Skripsi. Dipublikasikan. Semarang: UNDIP

Prasetyo, E. T dan Sri Purwantini. 2017. An Influence Analysis of product Quality, Brand Image, And Price on The Decision to Buy Toshiba Laptop. Economic \& Business Solution Journal, Vol.1. Number 2.11-18.

Priyatno, D. 2013. Analisis Korelasi Regresi dan Multivariate dengan SPSS. Penerbit Gaya Media.

Putro, S.W., Semuel, H., \& Brahmana, R.K. 2014. Pengaruh Kualitas Layanan dan Kualitas Produk terhadap Kepuasan Pelanggan dan Loyalitas Konsumen Restoran Happy Garden Surabaya. Jurnal Manajemen Pemasaran, Vol. 2, No.1, 1-9.

Salim, W., \& Subagio, H. 2013. Analisa Pengaruh Retail Mix Terhadap Keputusan Pembelian Konsumen Di Kampoeng Roti Nginden Surabaya. Jurnal Manajemen Pemasaran Petra, 1, 1-10.

Sugiyono. 2013. Metode Penelitian Manajemen. Bandung: Penerbit Alfabeta.

Tjiptono \& Chandra. 2012. Pemasaran Strategik (2nd ed.). Yogyakarta: Andi.

Xian, Gou Li, et al. 2011. Corporate-, Product-, and User-Image Dimension and Purchase Intentions. Journal of Computers. Vol 6, 1875-1879. 